\title{
Peran Komunikasi antara Guru dan Murid dalam Membangun Minat Belajar di Komunitas Jendela Jakarta
}

\author{
Rizki Putri Nadia, Santi Delliana \\ Program Studi Ilmu Komunikasi, Fakultas Industri Kreatif Institut Teknologi dan Bisnis Kalbis 1 \\ Jalan Pulomas Selatan Kav. 22, Jakarta Timur. \\ Email: anastasia.santi@kalbis.ac.id
}

DOI: https://doi.org/10.21107/ilkom.v14i1.7019

\begin{abstract}
ABSTRAK
Komunitas Jendela Jakarta adalah komunitas yang berfokus pada pendidikan non-formal. Relawan komunitas memiliki latar belakang pendidikan yang berbeda, sehingga gaya mengajar masing-masing relawan juga berbeda. Psikologi dan gaya belajar siswa yang bervariasi membutuhkan pola komunikasi baru. Studi ini meneliti pola komunikasi guru dalam membangun minat siswa di Komunitas Jendela Jakarta dan bagaimana mengatasi hambatan komunikasi yang ditemukan selama proses pembelajaran. Metode yang digunakan dalam penelitian ini adalah kualitatif. Informan dalam penelitian ini adalah guru, sukarelawan, dan koordinator Divisi Hubungan Komunitas Jendela Jakarta. Pengumpulan data dilakukan dengan melakukan wawancara, observasi, dan studi dokumentasi. Hasil penelitian menunjukkan bahwa pola komunikasi yang digunakan oleh sukarelawan Komunitas Jendela Jakarta untuk meningkatkan minat belajar adalah melalui pendekatan pribadi, diskusi, dan negosiasi. Metode pembelajaran menggunakan media visual dan berbicara tentang pembelajaran aktif. Namun, kendala dalam proses pembelajaran masih sering ditemukan dalam bentuk kurangnya antusiasme, perilaku bodoh, dan melarikan diri dari kelas karena mereka tidak tertarik. Solusi yang biasa adalah memberikan kebebasan untuk bermain di luar kelas untuk menghilangkan kebosanan, mendekati siswa, membujuknya perlahan untuk mau mengikuti pelajaran.
\end{abstract}

Kata Kunci: pola komunikasi, komunikasi pendidikan, minat belajar.

\begin{abstract}
Komunitas Jendela Jakarta is a community focused on non-formal education. Community volunteers have different educational backgrounds, so the teaching styles of each volunteer are also different. Psychology and learning styles of students who vary require a new pattern of communication. This study examines the communication patterns of teachers in building student interest in Komunitas Jendela Jakarta and how to resolve communication obstacles that are found during the learning process. The method used in this research is qualitative. The informants in this study were the teacher, volunteer, and coordinator of the Komunitas Jendela Jakarta Relations Division. Data collection is done by conducting interviews, observations, and documentation studies. The results showed that the communication patterns used by Komunitas Jendela Jakarta volunteer teachers to increase interest in learning were through a personal approach, discussing, and negotiating. The learning method uses visual media and talks about active learning. However, obstacles in the learning process are still often found in the form of lack of enthusiasm, ignorant behavior, and running away from class because they are not interested. The usual solution is to provide freedom to play outside the classroom to get rid of boredom, approach the student, persuade him slowly to want to follow the lesson.
\end{abstract}

Keywords: communication pattern, educational communication, learning interest

\section{Cite this as :}

Nadia, R., P. \& Delliana, S (2020). Peran Komunikasi antara Guru dan Murid dalam

Membangun Minat Belajar di Komunitas Jendela Jakarta. Jurnal Komunikasi, 14(1),

83-94. doi : https://doi.org/10.21107/ilkom.v14i1.7019

Article History :

(C) Author (s) 


\section{PENDAHULUAN}

Komunitas Jendela Jakarta adalah suatu komunitas yang berfokus pada bidang pendidikan non formal. Komunitas Jendela Jakarta mengajak setiap orang yang berminat untuk berbagi dengan berbagai cara yang dilakukan. Caranya dapat berupa partisipasi dengan berbagi ilmu pengetahuan, kreativitas, buku, uang, alat tulis, alat musik, atau apapun yang bisa dilakukan. Tujuan dari komunitas ini adalah meningkatkan prestasi siswa yang bergabung di Jendela Jakarta tanpa pungutan biaya apapun. Komunitas Jendela Jakarta menyebut nama sekolah disetiap lokasinya yaitu Perpustakaan, di Jakarta sendiri Perpustakaan Jendela Jakarta terbagi di 3 lokasi yaitu perpustakaan Manggarai yang bertempatkan di RPTRA Manggarai, Perpustkaan Sungai Bambu di RPTRA Sungai Bambu dan Perpustakaan Serpong di Bumi Perkemahan Lembah Hijau, Babakan Serpong.

Setiap tahunnya Komunitas Jendela membuka kesempatan kepada setiap orang dari berbagai usia dan profesi untuk mendaftarkan diri menjadi pengajar relawan di Komunitas Jendela. Menurut Joyce L. Epstein (Epstein, 2019, p. 73) Kegiatan sukarela untuk membantu komunitas dengan bekerja bersama mendukung program pendidikan. Kegiatan mulai dari merekrut dan melatih sukarelawan; mengatur jadwal para sukarelawan, lokasi, dan kegiatan untuk sukarelawan; serta mengenalkan sukarelawan kepada orang tua yang berperan sebagai audiens jika terdapat acara/pertunjukan yang diselenggarakan oleh siswa. Kegiatan ini memungkinkan relawan untuk bekerja dengan sukarela baik secara reguler atau hanya sesekali untuk membantu dan mendukung kegiatan siswa di lokasi masing-masing.

Di Jakarta sendiri Komunitas Jendela memiliki 3 lokasi yang terletak di Manggarai, Sungai Bambu dan Serpong. 3 lokasi tersebut masing-masing terbagi menjadi 4 kelompok belajar yaitu kelas A Kecil untuk siswa TK, kelas A besar kelas 1-2 SD, kelas B 3-6 SD, kelas C SMP-SMA. Untuk di Perpus Manggarai jadwal mengajarnya setiap hari
Sabtu dan Minggu jam 13.30-15.00, Perpus Sungai Bambu hari Minggu jam 09.00-11.30, Perpus Serpong hari Minggu jam 13.00-14.30. Durasi belajar disetiap Perpustakaan memiliki waktu yang sama yaitu 1 (satu) setengah jam perharinya, diluar jadwal yang sudah ditentukan pihak Komunitas Jendela juga punya jadwal yang di infokan perminggu nya untuk kelas diskusi, seni atau apapun.

Setiap minggunya tema materi setiap kelas sudah disiapkan oleh pihak tim program, setiap relawan bisa menyesuaikan waktu, tempat dan materi sesuai dengan kemampuan masing-masing. Tata cara mengajar seperti guru dan siswa pada umumnya. Karena setiap relawan harus membuat dan menyiapkan materi yang harus diberikan kepada anakanak, relawan harus membuat materi semenarik mungkin, berkomunikasi dan berinteraksi sebaik mungkin, agar siswa mau mendengarkan dan mengikuti proses belajar dengan baik dan ilmu yang disampaikan oleh relawan dan mendapatkan hasil sesuai yang di harapkan. Anak didik diarahkan pada kegiatan-kegiatan dengan menerapkan metode pembelajaran yang biasa disebut metode kinerja atau metode penerapan.

Setiap minggunya para relawan yang mengajar di dampingi divisi program dari Komunitas Jendela Jakarta untuk diskusi materi-materi yang relawan siapkan sebelum diberikan kepada murid. Setelah proses belajar mengajar selesai para relawan dan divisi program kembali berkumpul untuk evaluasi. Setiap relawan harus menceritakan keadaan kelas mulai dari perkembangan murid, hambatan yang terjadi saat proses belajar mengajar dan materi yang pas untuk pertemuan selanjutnya. Semua itu rutin dilakukan demi memantau perkembangan pada murid dan memperbaiki segala hambatan yang ada.

Komunitas Jendela membuka peluang dan kesempatan untuk anak-anak Indonesia para calon penerus bangsa untuk mendapatkan pendidikan non formal yang bertujuan untuk menambah pengetahuan dan ilmu mereka ditengah keterbatasan biaya mereka untuk mendapatkan pendidikan, 
selain itu juga Komunitas Jendela hadir di dalam kehidupan anak-anak untuk membangkitkan kecintaan mereka terhadap membaca, membentuk kemandirian belajar mereka. Untuk relawan nya sendiri, Komunitas Jendela berdiri agar setiap relawan yang bergabung dapat membagikan ilmu mereka lebih bermanfaat untuk orang lain, mengasah kemampuan kepemimpinan mereka melalui berbagi pengetahuan dan kasih sayang untuk teman-teman kecilnya. Para relawan yang sudah bergabung di Komunitas Jendela ini jumlahnya sudah cukup banyak, mereka berasal dari berbagai profesi. Mulai dari pelajar Sekolah Menengah Atas (SMA) hingga pekerja kantoran.

Dalam proses pembelajaran, materi telah disiapkan oleh tim program namun relawan dibebaskan untuk menyesuaikan atau berkreasi dalam menyampaikan materi. Ada yang dengan menggunakan media seperti gambar, boneka, buku ajar, tulisan di papan tulis bahkan bermain sambil belajar. Hal ini mengingat relawan komunitas memiliki latar belakang pendidikan yang berbeda-beda sehingga gaya dan teknik mengajar setiap relawan juga berbeda.

Disamping itu, psikologi dan gaya belajar anak-anak didiknya yang bervariasi menuntut adanya pola komunikasi yang menarik. Hal ini penting agar siswa mau mengikuti proses belajar dengan baik sehingga ilmu dapat diserap dengan baik. Pola komunikasi merupakan suatu pola hubungan yang melibatkan dua orang atau lebih dan dilakukan melalui penyampaian pesan secara tepat oleh komunikator sehingga komunikan memahami pesannya dan memberikan feedback dengan baik.

Namun demikian sering ditemui siswa yang malas, manja, menangis atau sering merengek dan tidak memiliki minat untuk belajar. Kemalasan mereka bias disebabkan oleh beberapa hal, bisa karena malas berpikir atau karena kurangnya perhatian orang tua dalam belajar. Siswa yang manja dapat terbentuk karena orang tua tidak tega untuk memarahi mereka sehingga membuat mereka menjadi manja. Merujuk pada hal tersebut, maka penelitian ini akan mengkaji pola komunikasi guru dalam membangun minat belajar siswa di Komunitas Jendala Jakarta serta cara menyelesaikan kendala komunikasi yang ditemukan selama proses pembelajaran. González-Howard (2016, p. 527) mengatakan komunitas berbentuk kelas terkadang terkendala dengan kehadiran dan kualitas pengajaran secara argumentatif, dipengaruhi oleh gerakan siswa yang masuk dan keluar pada komunitas kelas, padahal kemampuan bahasa Inggris mereka meningkat setelah mengikuti kelas ini.

Cara berkomunikasi yang digambarkan dengan adanya kecenderungan pada gejala umum dan terjadi dalam suatu kelompok tertentu disebut dengan pola komunikasi (AW, 2011, p. 116). Pola ini menjadi model dalam proses komunikasi yang akhirnya tertemukan pola yang sesuai dan dapat dengan mudah dipergunakan dalam berkomunikasi. Pola, model, bentuk dan bagian-bagian kecil akan tampak pada proses komunikasi. Hal ini yang menjadi penting dalam penelitian untuk melihat pola komunikasi antar pribadi. Seperangkat harapan yang terdapat pada partisipan melalui jalinan hubungan yang ditunjukkan dengan perilaku tertentu dalam berkomunikasi dapat dikatakan pola komunikasi antar pribadi.

Komunikasi adalah suatu hal pokok bagi setiap orang dalam berhubungan, begitu pula organisasi yang memiliki tujuan juga menggunakan komunikasi sebagai sarana agar tujuannya tercapai. Berdasarkan pendapat Maman Ukas (Ukas, 2000) mengenai ungkapan tujuan komunikasi, hal tersebut sudah sesuai. Tujuan komunikasi menurutnya:

1. Menetapkan serta menyebarkan tujuan dari suatu organisasi

2. Mengembangkan rencana-rencana untuk mencapai tujuan organisasi

3. Mengorganisasikan sumber-sumber daya manusia dan sumber daya lainnya secara efektif dan efesien

4. Memilih, mengembangkan, menilai anggota dalam organisasi 
5. Memimpin, mengarahkan, memotivasi dan menciptakan suatu iklim kerja sehingga setiap orang mau memberikan konstribusi.

Dalam prosesnya, komunikasi merupakan suatu proses sosial yang dilakukan untuk menyampaikan suatu pesan, informasi dan gagasan atau bisa juga bertujuan untuk mengungkapkan perasaan seseorang. pesan atau informasi yang disampaikan bisa secara langsung ataupun menggunakan media perantara. sama hal nya dengan proses belajar mengajar, terdapat komunikasi antara komunikator seorang guru dan komunikan yaitu murid dan terdapat pola komunikasi didalam proses belajar mengajar yang menghasilkan suatu efek atau dampak tertentu. yaitu adanya suatu pembentukan dan pengalihan pengetahuan, keterampilan yang menjadi tujuan komunikator sebagai seorang guru.

Komunikasi instruksional antara guru dan murid dalam kegiatan belajar mengajar siswa di Komunitas Jendela Jakarta belum memenuhi kriteria-kriteria strategi komunikasi instruksional dengan tepat untuk pengembangan kecerdasan sosial dan emosi anak. Hal ini disebabkan adanya beberapa permasalahan yang membutuhkan perhatian khusus dari pihak dalam maupun luar sekolah. Karena penelitian ini hanya meneliti peran komunikasi instruksional antara guru dan siswa, maka diharapkan penelitian selanjutnya dapat meneliti secara mendalam proses dan pendekatan dalam strategi komunikasi instruksional dari awal kegiatan belajar mengajar (Rianditha, 2018, p. 1).

\section{METODE PENELITIAN}

Paradigma merupakan serangkaian pandangan yang saling berkaitan mengenai fenomena-fenomena didunia. Dalam sebuah study, paradigma berorientasi sebagai kerangka filosofis dan konseptual. Paradigma peneliti akan membawa kepada pemahaman terhadap metodologi penelitian (Mulyana, 2017, p. 112). Didalam metodologi penelitian tersebut terdapat teori-teori dan metode- metode. Metode yang dilakukan oleh peneliti dalam peneitian ini adalah, paradigma konstruktivis.

Persepektif interaksi simbolis dan perspektif struktuan fungsional mempengaruhi paradigma konstruktivis. Dalam perspektif interaksi simbolis, manusia dikatakan secara kognitif aktif dan kreatif dalam mengembangkan responsnya terhadap stimulus yang diberikan. Penelitian ini menggunakan metode kualitatif, dimana penelitian metode kualitatif memusatkan perhatiannya pada prinsip umum yang mendasari perwujudan atau pola-pola. Gejalagejala sosial budaya yang terjadi dalam masyarakat, dianalisis menggunakan kebudayaan yang ada dalam masyarakat tersebut agar memperoleh gambaran mengenai pola-pola yang berlaku. Pola-pola yang telah ditemukan tersebut dianalisis lebih dalam lagi menggunakan teori yang objektif. Sasaran kajian dalam penelitian kualitatif adalah pola-pola atau prinsip-prinsip umum, mendasar, dan mencolok serta berdasarkan kehidupan manusia. Maka gejala-gejala yang dianalisis tidak dapat atau tidak harus menggunakan kebudayaan yang bersangkutan sebagai kerangka acuannya.

Informan dalam penelitian ini adalah guru, relawan, dan koordinator Divisi Humas Komunitas Jendela Jakarta. Pengumpulan data dilakukan dengan melakukan wawancara, observasi, dan studi dokumentasi (Sugiyono, 2017, p. 224). Data yang telah diperoleh kemudian dianalisis melalui tiga tahapan yaitu reduksi data, penyajian data, dan penarikan kesimpulan. Penelitian ini berlangsung pada bulan Februari 2019 hingga bulan Mei 2019 yang mencakup seluruh proses, mulai dari pengumpulan data, analisis data hingga pembuatan laporan. Pemilihan waktu tersebut didasarkan pada jadwal yang telah sepakati antara peneliti dan narasumber dari pihak Komunitas Jendela Jakarta Manggarai. Karena di akhir bulan Mei peneliti mengumpulkan data maka pada bulan Juni peneliti menganalisis dan menginterpretasi hasil temuan penelitian serta melengkapi laporan penelitian sesuai dengan prosedur 
yang sudah ada. Lokasi penelitian berada di lokasi proses belajar mengajar Komunitas Jendela Jakarta di Manggarai berlangsung, tepatnya di Jl. Manggarai Utara VI no.17 RT. VI RW.01 Tebet, Jakarta Selatan

\section{Pelaksanaan Wawancara}

1. Wawancara Informan 1 (Citra Ayu-Ketua Koordinator Komunitas Jendela Jakarta)

Tanggal : 23 Juni 2019

Waktu : $16.00 \mathrm{WIB}$

Tempat : Perpustakaan Komunitas Jendela Jakarta

2. Wawancara Informan 2 (Intan-

Koordinator Divisi Humas)

Tanggal : 22 Juni 2019

Waktu : $16.00 \mathrm{WIB}$

Tempat : Perpustakaan Komunitas

Jendela Jakarta

3. Wawancara Informan 3 (Mega-Guru Relawan)

Tanggal : 22 Juni 2019

Waktu : $13.00 \mathrm{WIB}$

Tempat : Perpustakaan Komunitas Jendela Jakarta

\section{HASIL DAN PEMBAHASAN}

Komunitas Jendela Jakarta dikelola dan digerakkan oleh para volunter yang bekerja secara sukarela dan berasal dari berbagai latar belakang. Fokus kegiatannya adalah pengembangan pendidikan dan mental anak terutama pada anak-anak yang kurang beruntung di kawasan sekitar Stasiun Manggarai. Komunitas Jendela Jakarta ini memiliki visi yaitu menjadi komunitas berjiwa muda yang fokus berkarya dan berkontribusi pada pendidikan anak-anak Indonesia.

Proses pembelajarannya dilakukan setiap hari pada sore atau malam hari, seperti belajar membaca, menghitung, menggambar, juga mengaji serta menghafalkan doa-doa serta surat-surat Al-Qur'an serta pelajaran di sekolah formal. Selain kegiatan belajar mengajar tersebut, komunitas ini juga mengadakan kegiatan lainnya akhir pekan yang berupa kegiatan program reguler, program tahsin, praktikum, one day one trip, cooking day, camping, nonton film bareng, serta seminar pendidikan.

\section{Fungsi Komunikasi}

Komunikasi adalah suatu proses pengiriman pesan, informasi ataupun gagasan yang disampaikan oleh komunitakor kepada penerimanya yang disebut dengan komunikan. Pesan atau informasi yang disampaikan bisa secara verbal mauapun non verbal, secara langsung maupun menggunakan suatu media seperti cetak ataupun elektronik. Hasil akhir yang diharapkan dari terjadinya proses komunikasi adalah, penerimaan pesan yang tepat dan jelas oleh komunikan. Ketua Koordinator Komunitas Jendela Jakarta, Citra Ayu, menerangkan bahwa terbentuknya komunitas Jendela Jakarta berawal dari mahasiswa UGM yang menjadi relawan korban pengungsian merapi di tahun 2011 dan terus berkembang sampai ke Jakarta pada tahun 2012.

\begin{abstract}
"Awalnya dari mahasiswa ugm yang membentuk komunitas relawan untuk adik-adik di pengungsian merapi di tahun 2011 dan terus berkembang sampai ke Jakarta di tahun 2012.”
\end{abstract}

Koordinator Divisi Humas Komunitas Jendela Jakarta Intan menerangkan jika terbentuknya komunitas ini ketika ada beberapa mahasiswa menjadi relawan pendidikan di pengungsian korban merapi. Karena sekolah masih belum berfungsi dengan baik saat itu jadi para mahasiswa memberikan alternatif agar anak-anak korban pengungsian bisa tetap belajar.

"Awalnya tuh ada mahasiswa yang menjadi relawan pendidikan di pengungsian korban merapi. Saat itu sekolah masih belum berfungsi dengan baik jadi mahasiswa ini memberikan alternatif pendidikan supaya anak-anak korban bencana ini bisa tetap belajar." 


\begin{abstract}
Guru relawan komunitas Jendela Jakarta, Mega, menerangkan bahwa terbentuknya Jendela Jakarta di Manggarai karena ada relawan yang pernah ikut serta di Jogja dan berniat untuk meningkatkan minat baca anak-anak kurang mampu.

"Kalau di manggarai sendiri awalnya karena relawan yang pernah ikut serta di Jogja berniat untuk meningkatkan minat baca untuk anak-anak kurang mampu."
\end{abstract}

Komunikasi yang baik dan benar membawa hasil yang sesuai dengan harapan, sebaliknya apabila komunikasi yang terjadi kurang tepat menimbulkan dampak yang negatif. Mengakui masi memiliki banyak kekurangan namun ada juga kelebihan, kedua belah pihak dapat menciptakan komunikasi yang efektif dan baik. Hubungan antar individu, guru relawan dan siswa, dijalin melalui komunikasi yang efektif dan dikembangkan menjadi hubungan yang bermanfaat dan saling menguntungkan.

Koordinator Divisi Humas Komunitas Jendela Jakarta Intan juga menambahkan bahwa yang dilakukan mahasiswa yang menjadi relawan pendidikan di pengungsian tersebut mendapatkan respons yang positif dari orang tua dan murid-murid disana. Karena mendapatkan respons positif inilah akhirnya terbentuk komunitas jendela yang ada di berbagi kota pada tahun 2011 .

\footnotetext{
"Terus juga respons yang di dapat sangat positif dari orang tua dan murid-murid disana akhirnya dibentuklah komunitas jendela ini diberbagai kota sesuai asal kakak-kakak relawan. Termasuk, di Jakarta yang berlokasi di manggarai."
}

"Sejak tahun 2011 yang berawal di kota yogya, kalau di manggarai sendiri sejak tahun 2012."

\footnotetext{
Berdasarkan hasil wawancara, informan menjelaskan bagaimana terbentuknya komunitas Jendela Jakarta dan bagaimana respons yang didapat juga bersifat positif. Sesuai dengan teori komunikasi yang mengungkapkan bahwa komunikasi diartikan sebagai proses pemindahan makna dalam
}

bentuk pemikiran atau informasi dari seseorang kepada orang lain dan tidak hanya melibatkan sekedar kata-kata yang digunakan dalam suatu percakapan, tetapi juga seperti ekspresi wajah, intonasi, dan sebagainya. Hubungan antar individu akan berkembang menjadi hubungan yang bermanfaat dan saling menguntungkan melalui terjalinnya sebuah komunikasi yang efektif.

\section{Unsur-unsur Komunikasi}

Unsur-unsur yang ada dalam seitap proses tentu mendukung keberlangsungan pembentukan suatu proses. Komunikasi juga melibatkan unsur dalam prosesnya, salah satunya unsur pesan. Unsur pesan dalam komunikasi merupakan seperangkat lambang bermakna yang disampaikan oleh komunikator.

Ketua Koordinator Komunitas Jendela Jakarta, Citra Ayu, menjelaskan bahwa kesan selama mengajar di komunitas jendela jakarta informan merasakan perasaan yang campur aduk seperti perasaan senang, emosi dan bahagia.

"Selama mengajar dan menjadi pengurus di Komunitas Jendela rasanya campur aduk, mulai dari seneng, emosi, bahagia."

Koordinator Divisi Humas Komunitas Jendela Jakarta, Intan mengatakan bahwa awalnya memiliki kesan yang terlihat sangat menyenangkan karena murid-murid terlihat kooperatif. Namun seiring berjalannya waktu semakin mengenal sifat murid-muridnya, semakin ada hambatan-hambatan yang dirasa.

"Untuk kesan awal semua masih terlihat
sangat menyenangkan dan murid2 bisa
sangat kooperatif, tapi seiring
berjalannya waktu semakin mengenal
sifat muridlah hambatan- hambatan
mulai dirasakan."

Lain halnya dengan yang dirasakan guru relawan di Komunitas Jendela Jakarta. Mereka mengatakan bahwa awalnya mereka merasa bahagia dengan melihat senyum adik- 
adik disana, tawa adik-adik disana, dan sifat manja adik-adik disana. Bahkan menurutnya beberapa dari adik-adik tersebut sangat pintar dan memiliki keinginan tinggi untuk belajar. Mereka juga mengatakan bahwa ia sangat diapresiasi. Tidak hanya itu, menurutnya pengurus dan para relawan yang lain juga sangat ramah.

"Kesan pertama yang aku rasain itu bahagia banget, ngeliat senyum adikadik disana, tawa mereka, manja mereka dan tidak sedikit dari mereka sangat pintar dan berkeinginan tinggi untuk belajar. Jadi aku merasa sangat di apresiasi. Pengurus dan relawan yang lain juga sangat ramah dan welcome. Kebahagiaan yang tidak terduga."

Adapun unsur lain yang melibatkan komunikasi, yaitu unsur respons dimana unsur ini berupa tanggapan atau seperangat reaksi pada komunikan setelah diterpa pesan. Maksudnya reaksi yang dilakukan oleh siswa setelah menerima pesan dari guru relawan.

Ketua Koordinator Komunitas Jendela Jakarta, Citra Ayu, menjelaskan bahwa ada banyak respons murid ketika diberikan materi seperti ada yang semangat, ada yang malas bahkan ada juga yang mencari alasan untuk tidak belajar dan ini menjadi tantangan sendiri bagi informan.

"Banyak respons yang mereka berikan, ada yang semangat, ada yang acuh, ada yang malas, ada yang berusaha mencari alasan untuk tidak belajar."

"Tantangan yang sering terjadi ya paling sikap adik-adik yang tidak mau mengikuti proses belajar mengajar, kelakuan-kelakuan jahil mereka.”

Koordinator Divisi Humas Komunitas Jendela Jakarta, Intan mengatakan bahwa ketika adik-adik di Komunitas tersebut diberikan materi, mereka terlihat suka dan semangat dalam mengikuti pelajaran. Mereka juga mengerjakan semua tugas dengan baik. Namun terkadang jika materinya dirasa membosankan, mereka sibuk sendiri sehingga belajar mengajar jadi tidak efektif. Ini pun juga menjadi tantangan tersulit ketika para murid tidak mau mendengarkan nasihat atau rayuan yang diberikan. Meskipun sudah negosiasi, mereka tetap malas belajar dan malah mengganggu teman yang lain.

"Ketika kami memberikan materi yang mereka suka, adik-adik sangat semangat mengikuti pelajaran, mengerjakan semua tugas dengan baik, tapi kalau materinya membosankan sibuk sendiri mereka dan proses belajar mengajar menjadi tidak wefektif." (Informan 2)

"Tw antangan yang paling sulit, ketika murid sudah tidak mau mendengarkan nasihat ataupun rayuan yang diberikan, negosiasi pun ditolak mereka tetap malas belajar dan mengganggu teman yang lain." (Informan 2)

Hal ini diperkuat oleh yang dikatakan guru relawan di Komunitas Jendela Jakarta. Ia mengatakan bahwa jika murid-murid tidak tertarik dengan materi yang diberikan, mereka tidak mau mengikuti proses belajar.

"Ketika mereka merasa tidak tertarik
terhadap materi yang diberikan,
sehingga tidak mau mengikuti proses
belajar mengajar dengan baik."
(Informan 3)

Selain itu ada unsur feedback yaitu tanggapan komunikan apabila tersampaikan atau disampaikan oleh komunikator kepadanya. Ketua Koordinator Komunitas Jendela Jakarta, Citra Ayu, menjelaskan bahwa murid-murid memberikan feedback positif dan negatif.

"Ada yang menunjukan dengan perkembangan mereka, ada yang malesmalesan kalau disuruh ngeerjain tugas, ada yang rajin banget bahkan terkadang materi yang kita kasih mereka udah paham."

Koordinator Divisi Humas Komunitas Jendela Jakarta, Intan mengatakan bahwa murid-murid memberikan feedback sangat positif, bahkan merekapun mampu mengerjakan tugas yang diberikan dengan cepat dan tepat. 
"Feedback yang mereka berikan sangat positif, bahkan mereka mampu mengerjakan tugas yang diberikan dengan cepat dan tepat. Mereka mau berusaha ketika merasa tidak bisa."

Guru relawan di Komunitas Jendela Jakarta juga mengatakan bahwa murid-murid memberikan feedback yang berbeda-beda. Ada yang memberikan respons positif dan ada yang bermalas-malasan belajar, bahkan ada yang mengganggu teman dikelas.

"Untuk feedback dari adik-adik jelas berbeda-beda, ada yang memberikan respons dengan hal positif dan yang malas-malasan belajar hanya mengganggu teman dikelas juga ada, sehingga mengganggu adik lain yang mau belajar."

Berdasarkan hasil wawancara informan menjelaskan bagaimana kesan mereka selama mengajar di Komunitas Jendela Jakarta, serta bagaimana respons dan feedback yang diberikan oleh pada murid di komunitas tersebut. Murid tersebut ada yang memberikan respons dan feedback positif maupun negatif. Hal ini sesuai dengan unsurunsur komunikasi tentang pesan, respons dan feedback. Unsur message dimana pesan yang merupakan seperangkat lambang bermakna yang disampaikan oleh komunikator. Pada unsur ini informan menunjukan kesan yang didapat selama mengajar di Komunitas Jendela Jakarta. Unsur respons dimana unsur ini berupa tanggapan, seperangat reaksi pada komunikan setelah diterpa pesan.

\section{Komunikasi sebagai Proses Sosial}

Dalam masyarakat, komunikasi juga berperan dalam menjembatani perbedaan yang ada karena komunikasi mampu memperbaiki kembali sistem sosial masyarakat dalam usahanya melakukan perubahan. Semuanya saling mempengaruhi dan melengkapi, sebagai hal nya hubungan manusia dengan masyarakat.

Ketua Koordinator Komunitas Jendela Jakarta, Citra Ayu, mengatakan bahwa teknik informan membangun komunikasi yang efektif dengan para murid yaitu dengan mendekatkan diri secara personal kepada para murid, mengajaknya berdiskusi agar para murid mau diajak belajar, dan menegur jika ada murid yang mulai mengganggu temannya.
"Deketin diri secara personal ajak
ngobrol atau diskusi biar mereka mau
belajar dengan benar, engga jarang negur
juga kalau udah ganggu temen yang
lainnya."

Koordinator Divisi Humas Komunitas Jendela Jakarta, Intan mengatakan bahwa untuk membangun komunikasi yang efektif dengan para murid dengan mengajak murid untuk berdiskusi dengan materi-materi yang tidak membebankan mereka. Sehingga mereka bias mengikuti dan merasakan nyaman tanpa ada rasa tertekan.

"Komunikasi yang baik mengajak
mereka berdiskusi, tidak membebani
mereka sebagai murid, sehingga mereka
bisa merasa nyaman tanpa rasa tertekan
karena komunitas ini sendiri kan
pendidikan non formal jadi lebih
membantu ke hal-hal yang belum
mereka kuasai disekolah. Sifatnya lebih
ke membantu mereka agar lebih pintar di
sekolah."

Guru relawan di Komunitas Jendela Jakarta juga mengatakan bahwa tidak jarang dirinya memberikan negosiasi kepada adikadik di Jendela Jakarta ketika malas belajar, seperti memberikan hadiah atau kelonggaran materi belajar. Murid-murid di komunitas tersebut lebih didekatkan secara personal dengan mereka dan diberikan kesempatan bertanya apa yang menjadi keluhan mereka dan memberikan win-win solution agar mereka tetap mau dan bersemangat dalam belajar.

"Tidak jarang saya melakukan negosiasi kepada adik-adik yang mulai tantrum atau malas belajar, untuk memberikan hadiah atau kelonggaran materi belajar. Lebih mendekatkan diri secara personal ke mereka, bertanya apa yang menjadi keluhan mereka dan memberikan win 
win solution agar mereka tetap mau belajar."

Berdasarkan hasil wawancara dengan informan untuk membangun komunikasi yang efetif dengan para murid, informan melakukan pendekatan secara personal, berdiskusi dan negosiasi. Hal ini sesuai dengan komunikasi yang berperan dalam menjembatani perbedaan. Komunikasi juga tidak lepas dari konteks sosialnya. Artinya konteks tersebut diwarnai oleh sikap, perilaku, pola, norma, pranata masyarakatnya.

\section{Komunikasi Pembelajaran}

Belajar atau learning adalah hasil dari pengalaman yang dapat mengubah tingkah laku yang relatif tetap. Komunikasi antar pribadi harus terjalin dengan harmonis antara relawan dan murid-murid pada kegiatan belajar mengajar. Komunikasi menjadi lebih efektif karena dipengaruhi oleh interaksi dari kedua belah pihak. Namun dalam proses tersebut relawan atau yang berfungsi sebagai pengajar tetap menjadi pemegang kendali. Keberhasilannya juga terdapat pada umpan balik positif pada proses komunikasi tersebut.

Proses belajar dapat dikatakan berhasil terjadi apabila seseorang menunjukan perubahan tingkah laku yang berbeda dari biasanya. Seperti, jika anak didik dapat melakukan sesuatu yang baru dan berbeda dari sebelumnya atau dapat membuktikan pengetahuan tentang fakta-fakta baru. Pesan dari pembelajaran ini menjadi kunci pada proses penyampaian gagasan komunikasi pembelajaran.

Ketua Koordinator Komunitas Jendela Jakarta, Citra Ayu, mengatakan bahwa muridmurid memiliki perkembangan yang baik selama bergabung di Jendela Jakarta.

\footnotetext{
"Mereka jadi bisa membaca dengan lebih lancar, bisa berhitung dengan baik, lebih tau sopan santun, karena kita disini sangat menjaga tingkah laku dan tutur kata mereka."
}

Koordinator Divisi Humas Komunitas Jendela Jakarta, Intan mengatakan bahwa murid-murid di Jendela Jakarta memiliki perkembangan yang sangat bagus. Mereka dilatih untuk belajar membaca dan berhitung. Tidak hanya itu, murid-murid juga diperbolehkan untuk bertanya mengenai pelajaran-pelajaran yang sulit dimengerti disekolah. Murid di Jendela Jakarta pub jadi lebih aktif, memiliki minat baca yang tinggi, menambah ilmu pengetahuan dan hal-hal positif.

"Perkembangan mereka sangat bagus, kami latih untuk belajar membaca, berhitung dan pelajaran-pelajaran yang sulit mereka pahami disekolah, mereka juga bisa bertanya di sini jadi pas disekolah mereka sudah memahami."

"Murid di jendela bisa lebih aktif, memiliki minat baca yang tinggi, menambah ilmu pengetahuan, dan halhal positif lainnya."

Guru relawan di Komunitas Jendela Jakarta juga mengatakan bahwa banyak perkembangan yang tidak hanya relawan yang merasakan, tetapi juga orang tua murid.

"Perkembangannya banyak dirasakan oleh kami sebagai relawan begitupun orang tua murid, terutama dikelas TK karena sekarang syarat masuk sd adalah bisa membaca adik-adik di jendela sudah bisa membaca dan berhitung sebelum mereka duduk di bangku sekolah dasar."

Suatu proses dipandang berhasil apabila kualitas yang dihasilkan lebih baik (output) daripada kualitas yang diberikan (input). Interaksi yang terjadi antara komponen belajar merupakan suatu proses belajar mengajar. Komponen proses belajar mengajar meliputi tujuan bahan, metode guru, siswa, fasilitas dan penilaian.

Ketua Koordinator Komunitas Jendela Jakarta, Citra Ayu, mengatakan bahwa muridmurid mendapatkan fasilitas berupa alat tulis, buku dan alat-alat lainnya.

"Alat tulis, buku, dan alat-alat lainnya yang mereka butuhkan saat proses belajar mengajar berlangsung." 
Koordinator Divisi Humas Komunitas Jendela Jakarta, Intan mengatakan bahwa komunitas Jendela Jakarta memfasilitasi murid-murid seperti buku, alat mewarnai dan media-media yang digunakan untuk pelengkap proses belajar mengajar.

"Komunitas jendela banyak
memfasilitasi seperti buku yang bisa
dibaca kapanpun, alat mewarnai, media-
media yang digunakan untuk pelengkap
proses belajar-mengajar, dll."

Guru relawan di Komunitas Jendela Jakarta pun mengatakan bahwa murid-murid diberikan fasilitas seperti alat tulis, buku dan kertas mewarnai.

"Alat-alat yang digunakan dalam proses belajar mengajar rata-rata difasilitasi oleh pihak jenjak, seperti alat tulis, buku, kertas mewarnai, dll."

Berdasarkan hasil wawancara
informan mengatakan bahwa untuk
membangun hubungan interpesonal yang
efektif dilakukan dengan metode melakukan
pendekatan kepada para murid dan
mengarahkan kegiatan secara langsung. Hal
ini sesuai yang dikatakan oleh Roger dalam
bukunya Muhammad Arni (Arni, 2005, p.
176) hubungan interpersonal menjadi efektif
apabila kedua pihak bertemu satu sama lain
secara personal.

Murid dibangun rasa empatinya terhadap orang lain, menggunakan komunikasi dengan tepat dan dapat saling memahami, saling menghargai, positif dalam menanggapi orang lain. Mereka juga diajarkan untuk menghayati pengalaman satu dengan yang lain, saling menerima empati orang lain (tidak tertutup), saling terbuka dan menjaga keterbukaan. Iklim yang mendukung diantara mereka dapat mengurangi kecenderungan gangguan yang mengakibatkan kesalahan makna. Murid juga memperlihatkan tingkah laku percaya dalam rangka memperkuat perasaan aman terhadap yang lain.

Observasi yang dilakukan sebanyak tiga kali di Komunitas Jendela Jakarta
Manggarai berawal di 16 Maret 2019, dengan mengikuti langsung kegiatan belajar mengajar yang dilakukan hari itu. Melihat kegiatan mereka, sikap relawan kepada anak didiknya, sikap anak didik kepada relawan dan kebetulan relawan yang hadir saat itu cukup banyak jadi proses belajar mengajar terlihat efektif adik-adik dapat mengikuti pelajaran dengan baik karena mendapat perhatian secara langsung dari relawan yang hadir. Mereka melakukan kegiatan mewarnai gambar yang sudah disiapkan oleh pihak Komunitas Jendela Jakarta. Walaupun tak jarang ada anak didik yang tantrum, mengeluh, tapi semua masih berjalan dengan sangat baik dan efektif hingga jam pelajaran selesai.

Kehadiran peneliti di observasi yang ke dua pada tanggal 25 Mei 2019 Komunitas Jendela Jakarta sedang mengadakan acara buka bersama yang bertemakan "Wonderful of Ramadhan". Peneliti mengikuti rangkaian acara tersebut Mulai dari hafalan JUZ AMMA, lomba desain kartu lebaran, lomba mewarnai, dan kegiatan seru lainnya. Sangat terlihat dari pihak coordinator dan relawan Komunitas Jendela Jakarta sangat kompak dalam mengurus acara, menjaga kenyamanan adik-adik agar tetap mau mengikuti rangkaian acara, hingga jam buka puasa tiba. Relawan atau guru di Komunitas Jendela Jakarta tidak sungkan untuk memangku anak didik mereka yang mengeluh atau bermalas-malasan, melakukan komunikasi secara interpersonal memang sangat paling tepat dilakukan untuk adik-adik yang masih sulit untuk di control mood nya. Selain itu juga selama tiga kali peneliti melakukan observasi secara langsung, banyak aturan yang dibuat oleh pihak Komunitas Jendela Jakarta untuk memberi sanksi terhdap anak didik mereka yang beretika atau bertutur kata tidak baik dengan sanksi denda sebersar Rp.1000 - Rp.5000. jumlah uang yang di dendakan tergantung kata apa yang diucapkan dan seberapa buruk kata yag diucapkan.

Dan observasi yang terakhir dilakukan oleh peneliti dengan membawa materi gambar untuk anak didik di Komunitas Jendela 
Jakarta, peneliti terjun langsung untuk membantu mengajar relawan atau guru yang lainnya. Materi yang dibawa oleh peneliti adalah "Mewarnai rumah ibadah". Menjadi seorang guru yang mengajar anak-anak kecil tidaklah mudah, karena harus menciptakan suasana yang menyenangkan, materi yang sangat menarik agar anak didik tidak mudah bosan, dan sikap yang ramah serta sabar, sangat diperlukan. Selama peneliti melakukan observasi, meneliti pola komunikasi yang dibetuk oleh para relawan terhadap anak didiknya cukup baik, karena mereka berasal dari latar belakang profesi yang berbeda-beda tidak semua paham bagaimana menjadi pengajar yang tepat, tetapi dengan teknik konvensional dan melakukan komunikasi secara antarpribadi semua proses belajar mengajar dapat berjalan efektif.

\section{PENUTUP}

Pola komunikasi yang digunakan oleh guru relawan Jendela Komunitas Jakarta untuk meningkatkan minat belajar adalah dengan pendekatan personal, berdiskusi, dan negosiasi. Adapun metode pembelajarannya dengan menggunakan media visual dan talkactive learning. Namun demikian hambatan-hambatan dalam proses pembelajaran masih sering dijumpai berupa kurangnya semangat, perilaku jahil, dan kabur dari kelas karena tidak tertarik. Kendalakendala dalam komunikasi juga dihadapi para relawan dan diatasi dengan cara membangun hubungan komunikasi interpersonal. Karena dari hasil wawancara informan mengatakan bahwa dengan membangun hubungan interpersonal para guru lebih bisa mengenal sifat dan pribadi para murid.

Solusinya yang biasa dilakukan adalah dengan memberikan kebebasan bermain diluar kelas untuk menghilangkan kejenuhan, mendekati sang murid, membujuknya secara perlahan agar mau mengikuti pelajaran. Komunikasi interpersonal yang efektif terus digunakan dalam proses pembelajaran di Komunitas Jendela Jakarta. Karena hal tersebut dapat membangun empati yang baik dengan para murid.

\section{DAFTAR PUSTAKA}

Arni, M. (2005). Komunikasi Organisasi. Jakarta: Bumi Aksara.

AW, S. (2011). Komunikasi Interpersonal. Yogyakarta: Graha Ilmu.

Epstein, J. L. (2019). School, Family, and Community Partnerships: Preparing Educators and Improving Schools (2nd ed.). California: Corwin. Retrieved from https://books.google.co.id/books?hl=i $\mathrm{d} \& \mathrm{l}=\& \mathrm{id}=\mathrm{c}$ YhlDwAAQBAJ \&oi $=\mathrm{fn}$ $\mathrm{d} \& \mathrm{pg}=\mathrm{PP} 1 \& \mathrm{dq}=$ The + Role + of + Com munication+Between+Teachers+and+ Students+in+Building+Interest + in $+\mathrm{L}$ earning + in + the + Community\&ots $=$ flq eUFk_SE\&sig=thk3qIky_pMxgTHrbtrreJC_5E\&redir_esc $=\mathrm{y} \# \mathrm{v}=$ onepage \&q=Th

González-Howard, M., \& McNeill, K. L. (2016). Learning in a Community of Practice: Factors Impacting EnglishLearning Students' Engagement in Scientific Argumentation. Journal of Research in Science Teaching, 53(4), 527-553.

https://doi.org/https://doi.org/10.1002 /tea.21310

Mulyana, D. (2017). Ilmu Komunikasi Suatu Pengantar (Revisi). Bandung: Remaja Rosdakarya.

Rianditha, N. (2018). Strategi Komunikasi Instruksional Guru Dan Murid Dalam Proses Belajar Mengajar Anak Usia Dini. Universitas Brawijaya. Retrieved from http://repository.ub.ac.id/163551/

Sugiyono. (2017). Metode Penelitian Kualitatif. Bandung: Alfabeta.

Ukas, M. (2000). Pengantar Bisnis Ilmu Menjual. Jakarta: Bumi Aksara. 
94 | Jurnal Komunikasi, Vol. 14 No. 01, Maret 2020: 83-94 